\title{
The Myth of the "Rainbow Nation": Xenophobia, Sexual Violence, and Racial Tensions in Period Pain by Kopano Matlwa
}

\author{
Mamadou Abdou Babou Ngom, Ph. D
}

\author{
Cheikh Anta Diop University of Dakar, Senegal, West Africa \\ English Department, Faculty of the Humanities \\ lamzosaf@gmail.com \\ mamadou35.ngom@ucad.edu.sn
}

\begin{abstract}
This paper sets out to analyze the phenomena that have contributed to debunk the myth of South Africa as a Rainbow Nation, in the aftermath of the country's liberation from decades-long yoke of racial oppression. The construction of the South African nation as a rainbow was metaphorically meant to reflect the ethnic and cultural as well as racial make-up of the land. This new frame of mind posited the banishment of racial and discursive practices and foregrounded the Zulu concept of 'ubuntu' as an inter-human praxis. The reality on the ground, so the paper argues, shows that under the veneer of multiculturalism lie a groundswell of ethnonationalism undercurrents that has a warped view of citizenship, which culminates in regular violent outbreaks of xenophobic sentiment targeted principally at African migrants from other parts of the continent. Also, our investigation project brings to light the pervasiveness of "corrective rape" the motivations of which point to the ingrained character of the patriarchal system in the country. The racial tensions that lie beneath the surface in Period Pain glaringly show that the racial demons of the past have taken on, so to speak, a new hue and have as yet to be completely laid to rest. The agency of the lead character encapsulates optimism steeped in humanity. Keywords - hate crime, ethno-nationalism, citizenship, racial tensions, Rainbow Nation, Ubuntu.
\end{abstract}

Kopano Matlwa (1985-) is a young South African novelist who packs a punch in her country's literary scene. A doctor and novelist all into one, Kopano Matlwa has authored three novels since the inception of her fictional career: Coconut (2007), Spilt Milk (2010) and Period Pain (2017), which serves as a basis for this paper. The strength of her fictional opus lies, inter alia, in the fact that it flags up core issues which have been dogging the Rainbow Nation since the demise of apartheid. Despite her young age, she's had literary awards conferred upon her in recognition of her talent and breakout success as a writer of outstanding promise-that is, the European Union Literary Award as well as the Wole Soyinka Prize for Literature in Africa.

The term "Rainbow Nation" is Rev. Desmond Tutu's brainchild. He first floated it in a September 1989 speech as he defied the then government led by Fredrick de Klerk, when he exhorted them to be out so they could see the racial and ethnic contours of post-apartheid South Africa: "You wanted us to show you that we are determined. You wanted us to show you that we are peaceful. Right! Mr de Klerk, please come here! We are inviting you Mr de Klerk, we invite you Mr Vlok, we invite all the cabinet. ... Come and see what this country is going to become!" (Qtd. in Allen 311). The repeal of institutionalized racism, so hoped the prelate, would pave the way for the advent of a society in which racial determinism took a backseat to such clerical values as love and peace against a background of multiculturalism. The rainbow people as a concept is a register of tolerance in the context of cultural diversity. It aims at a praxis of life embedded in integration as opposed to rejection. Nigerian top-flight thinker Wole Soyinka captures the spit of the said concept, and contends that, "it claims to a fusion of humanity or, at the very least, a communal blending, and offers the prospect of an integrated consciousness that speaks to a collective identity, or, at least, one that is in formation" (24). The wholeness that the word "rainbow" encapsulates is a foil to the divisiveness conveyed by apartheid-that is, "separate development" in Afrikaans. To be sure, a strong consciousness about the necessity for a common identity acts a bulwark against the demons of exclusion that feeds on race-based narrative. The sanguine vistas about postliberation South Africa were anchored in a deep-seated belief in the Xhosa concept of Ubuntu, whose moral purport emphasizes mutual interdependence. To put it differently, Ubuntu is the yardstick by which humanness is measured. Rev. Tutu elaborates upon the philosophy behind Ubuntu: 
It has to do with what it means to be truly human. It refers to gentleness, to compassion, hospitality, to openness to others, to vulnerability, to be available for others, and to know that you are bound with them in the bundle of life, for a person is only a person through other persons. (121-2)

Ubuntu is a way of life that is incommensurate with the ideology of exclusion. The construction of the concept "Ubuntu" as a lodestar in post-racial South Africa reflected an unflagging determination to not allow the searing memories of the past to overshadow the driving necessity to work towards reconciliation between those who underwent the gruesomely awful sentence of history, and the agents of violence. Tutu and his like-minded fellow strove flat out to not turn the tables of racial oppression on white minority out of vengeful spite.

The 1994 democratic elections formally sounded the death knell of institutionalized racism, commonly known as "apartheid", in South Africa, and heralded the entry of the country into the democratic era. Owing to the long history of subjection that blacks and other people of colour had gone through at the hands of white minority rule, there were fears that the downtrodden of yesteryear might be tempted to go down the road of revenge. Thankfully, though, those fears were not realized. Indeed, the icon of black resistance to apartheid's ingrained belief in love and tolerance went a long towards deactivating the psychological yearning for revenge amongst blacks. He was able to talk his fellow blacks into mending fences with whites despite the weight of history. As he said in his 1994 presidential inaugural speech:

\section{We enter into a covenant that we shall build a society in which all South Africans, both black and white, will be able to walk tall, without any fear in their hearts, assured in their inalienable right to human dignity-a rainbow nation at peace with itself and the world. (Qtd. in Dickson 116)}

He foregrounded reconciliation and, perhaps most importantly, forgiveness as key to preventing the yawning psychological and physical wounds (spawned by decades of race-driven oppression) from putting paid to the likelihood of a multiracial society following the abrogation institutionalized racism. His submission that he "cherished the idea of a democratic and free society in which all persons live in harmony and with equal opportunities" (Qtd. in Howarth and Walton 159) meant that he had left no stone unturned to make sure that the lust for revenge that gripped many a South African black did not materialize. The yoke of racial oppression with its heavy manifold human toll is a thing of the past. Granted. Still post-racial South Africa is agonizingly beset with multifaceted travails that in the fullness of time might jeopardize the effort and energy exerted to mediate a post-conflict society free from racial or ethnic hate.

Xenophobia, rape and excruciating destitution (which drives the unflattering high rate of crime that South Africa boasts) are, inter alia, the bane of post-apartheid South Africa. The pervasiveness of poverty and the obnoxious recurrence of rape as well as the repetitive outbreaks of xenophobic onslaughts on African immigrants make a mockery of the much touted concept of the Rainbow Nation. This also vindicates those free-wheeling South Africans who from the get-go regarded the rainbow concept as a pipedream: "The politics of the rainbow nation is unlikely to realize the consolidation of democracy. That it would do so is perhaps one of the biggest myths of the South African transition" (Habib 31). Despite South Africa being touted as a shining example of a harmonious multicultural society, harrowing xenophobic violence cum the nefarious phenomenon of rape raise their ugly head in a mind-blowing repetitive pattern that appalls not only South African men and women of conscience but also the international community. There have been loads of violent xenophobic practices since South Africa's entry into the democratic era. Still those of May 2008 take the biscuit. Xenophobic violence and corrective rape fall into the category of what is termed "hate crime". A hate crime can be defined as "criminal conduct which is motivated by the perpetrator's prejudice or bias, commonly referred to as 'hate', towards the victim's race, ethnicity, gender, sexual orientation, religion, disability and several other victim characteristics" (Naidoo 53-4). The FBI's definition of the term reads as follows: "A hate crime, also known as bias crime, is a criminal offence committed against a person, property, or society that is motivated, in whole or in part, by the offender's bias against a race, religion, disability, sexual orientation, or ethnicity/national origin" (Ross 346). As regards the Organization for Security and Cooperation in Europe, it takes hate crime to mean "a criminal act committed with a bias motive" (16). It follows from the foregoing that for an act to qualify as hate crime it has to carry a bias motive as well as constituting a crime. What makes for the bias motivation lies in "the offender's prejudice toward the victim based on a characteristic that represents a deep and fundamental part of a shared group identity, such as race, language, religion, ethnicity, nationality, gender or other characteristics"(ODIHR ${ }^{1}$ Qtd. in Gail Mason et. al 32). Indeed, one person or a whole

\footnotetext{
${ }^{1}$ ODIHR stands for the Office for the Democratic Institutions and Human Rights. 
group can be a lightning rod for a hate crime. The perpetrator of a hate crime is driven by a desire to publicly and violently vent his ill will against an individual or a community randomly selected, for they are regarded as not fitting into a set of normative ideals; it is intended to teach a lesson, and, consequently, conceived of as a kind of message conveyor: "They [hate crimes] are different from other crimes in that the offender is sending a message to members of a certain group that they are unwelcome in a particular neighbourhood, community, school or workplace" (Diaz and O'Hanlon 141). Hence the term "message crime" as an alternative to "hate crime". Plainly, "corrective rape" and "xenophobia" exemplify two cases of hate crimes that might in the fullness of time mar (unless they are effectively remedied) the social and political fabric of the Rainbow Nation.

"Corrective rape", aka "curative rape", is a scourge in modern-day South Africa. As the adjective "corrective" or "curative" suggests, it is marked off from heterosexual rape by its supposed healing properties: "'Corrective rape' seeks to justify the rape of those people who are perceived not to conform -or to disrupt-expected gender roles, behaviour and or presentation" (Nel and Judge 24). This fits into what Vines Basdeo calls "rape myths", viz., "a series of misplaced beliefs that hold that the victim is somehow at fault for being raped" (Basdeo 115). Perpetrators somewhat hold the moral high ground over their victims as they seek to redress 'imaginary wrongs' caused to society. They are knights in shining armour of sorts. What's pitiably contradictory in the phenomenon of "corrective rape" is that its agents destroy for the sake of allegedly 'curing'. Undoubtedly, "curative rape" wreaks a most heavy toll on both the victim and the group to which he or she belongs. Speaking of "xenophobia", it has raised its ugly head many times since the abrogation of apartheid that ushered in the democratic era in South Africa. Despite being a worldwide phenomenon, recurrent xenophobic outburst in South Africa geared towards migrants of African origin has shaken the foundations of the Rainbow Nation's democracy, and scorned the much touted concept of "Ubuntu". Etymologically, the word stems from the Greek language; it's, indeed, the conflation of "xenos", meaning "foreigner" or "stranger", and "phobia" that translates as "fear". The Oxford Advanced Learner's Dictionary defines "xenophobia" as "a strong feeling of dislike or fear of people from other countries" ( $8^{\text {th }}$ Edition). Harris equates it with "a negative attitude towards foreigners, a dislike, a fear or a hatred" (70). Still, he is at pains to point out that xenophobic people are not simply driven by a dislike or fear of the "outsider": "It [xenophobia] is not just an attitude: it is an activity. It is not just a dislike or fear of foreigners: it is a violent practice that results in bodily harm and damage" (170). Xenophobic sentiment seeks to foster www.ijels.com exclusion and intolerance. It never appears in a vacuum. Rather, it is the abysmal outlet of long-standing pent-up grievances over crass destitution. Indeed, against a background of rampant poverty, immigrants are fair game for xenophobic attacks from nationals as they are perceived as spoilsports in terms of job opportunities. The wanton rejection of the "foreigner" that betrays itself in xenophobia echoes the hatred for "otherness" that racism epitomizes. Xenophobia and racism may not come to the same thing from a definitional perspective, but they are two sides of the same coin:

Like xenophobia, racism positions its target groups as strangers, outsides, allochthones (sic). Racist or xenophobic groups create the others onto whom they project what they despise and fear about themselves; they exclude, disgrace, stigmatize and vilify the out-groups . . . Both racism and xenophobia enable the in-groups to justify their control over the means of power, prestige, and survival. They are both ideological rationales for intra-group aggression, violence and mass extermination. (Matsinhe 46)

In the context of post-racial South Africa, the scourge of hate crimes, and undercurrents of racism bespeak the bumpiness of the road to full-blown reconciliation. Little wonder that it constitutes the staple diet of post-1994 South African literature. Wildly cognizant that a writer's worth is measured by the degree to which he or she is steeped in the consciousness of his/her time, South African novelists, not the least of whom is Kopano Matlwa, see it as their duty to spotlight the manifoldl ills of their society with an eye to effecting change.

Period Pain is Kopano Matlwa's attempt to paint the picture of a society whose failure to live up to the promises of its liberation from decades of race-based oppression has spawned a general sense of malaise, an atmosphere of disenchantment. Written in diary form, the novel recounts the story of Machacheba (aka Chaba), a physician in her own rights coupled with a kind of conscience objector. Deeply religious, by turns wittily priceless and with gravistas in her narrative, Masechaba goes by the ethos of the Christian faith after the fashion of her mom thanks to whom she manages to secure a position in a government hospital (27). What she calls "disloyal friends", i.e., "the Gini coefficients, the shrinking economy, the legacy of apartheid, the unachieved millennium goals, and human resource constraints" (27), compound the state of a health system that is going downhill, thereby making it even more difficult for South Africans to cope. On top of this, newbie doctors' and interns' inexperience wreak havoc in hospitals: "How many people do we kill monthly, weekly, daily, all in the name of learning?" (31). Staffers are so overstretched 
that both in-patients and outpatients are not attended to every bit as well as they should be. Consequently, she happens to wish that patients on the danger list passed away so that she can have it in her to dedicate herself to the ones who have a chance of surviving (41). The female narrator works like hell to display the depth of her humanity as she struggles to come to terms with an array of woes: her own menstruation-related problems, the headache from her older brother's suicide not to mention the general sense of social malaise gripping her country. Chaba is so exercised about the earth-watering level of corruption and xenophobia as well as racial tensions that she teeters, at times, on the brink of snapping. Pushed to breaking point by the unabated wave of onslaughts on black African immigrants, she takes the plunge and files a petition in an endeavour to stop the rot. This no-nonsense move makes her a quisling in the eyes of her fellow compatriots and is, quite unexpectedly, gangraped. To cap it all, she conceives from the rape. After flirting with the idea of having an abortion for a moment, she forgoes it and decides, despite the odds being stacked against her, to carry the foetus to full term. Meanwhile, Nyasha (Chaba's colleague and Zimbabwean friend) leaves South Africa for Canada out of dissatisfaction for the raw deal that is meted out on African migrants, not the least of whom are those from neighbouring Zimbabwe. Masechaba feels betrayed upon learning that her boon companion has shaken the dust of South Africa off her feet.

Period Pain captures the dismal travails of a nation still reeling from the demons of the past. Admittedly, the demise of apartheid was supposed to phase in an era hallmarked by plenty and absence of racial determinism that had long been the social and political stock in trade of South African society. Kopano Matlwa's book stands as a decided reminder that there is a long way to go before the expectations of post-1994 are fulfilled every inch. In a land mired in crass destitution, under-resourced hospitals, harrowing expressions of hate crimes-you name it-, Masechaba epitomizes the human face of an uphill struggle against injustice of any ilk. Pretty much all through the narrative she goes out of way to decry in no uncertain terms the political and social ills plaguing her society. At one point, she regrets realizing her dream gig, namely being a

\footnotetext{
2 Eighteenth-century highly percipient German thinker, Arthur Schopenhauer, regards "Sympathy" and "Envy" as existing in every human being. Speaking about their origin, Schopenhahuer makes the contention that "they spring from the inevitable comparison that he [man] draws between his own lot and that of the others" (7). Depending upon the way the individual is moved, he adopts either disposition. The thinker is at pains to emphasize the primacy of "sympathy" over "envy" as a most valuable human trait. Indeed, Envy somewhat has the potential of driving a wedge between
}

doctor: "...I was so foolish to think that being a doctor, that six years at medical school, would bring me happiness. All it's brought me is pain and confusion" (34-5). There is a general sense of seemingly intractable dysphoria that belie official narratives that paints a glowing picture of the Rainbow Nation. Masechaba waxes indignant as she describes the agonizingly distressing conditions patients find themselves in:

There is a weight on my chest, and I try to breathe it off, but I can't. So when the patients die, I'm relieved. I tell myself it's better for them to die. They are suffering, they are in pain. . . I'm tired of being reminded of how little I can do. I'm tired of the drips that keep coming out. I'm tired of seeing them eat their poo and drink their pee. I'm tired of seeing them go mad. I'm tired of watching their families come every day and look to me for answers I cannot give them. I'm tired of working with people who don't care, who are dead like me. (34)

This tirade of disenchantment with the new dispensation reflects a high level suck in terms of the health system in democratic era South Africa. Chaba puts herself in the skin of the downtrodden to gauge the degree of their suffering. This speaks volumes about the strength of her moral compass. Calling out wanton human suffering is a measure of sympathy which, in Schpenhaurian philosophy, is a moral virtue ${ }^{2}$. Despite being a doctor in her own rights, she does not feel fulfilled, thereby adding to the poignancy of her predicament. She has gone through fire and water to realize her calling of being in the caring profession. From a philosophical vantage point, her anticlimactic feelings betokens, in no small measure, the illusive nature of the concept of happiness. Arthur Schopenhauer posits that when we harbour dreams of happiness in the future we are building castles in Spain. The general drift of life is such that our hopes are always prone to be checkmated by untold happenings. He writes:

Life itself presents as a continual deception, in small matters as well as in great. If it has promised, it does not keep its word, unless to

human beings whilst Sympathy dwindles the yawning gap between "Self" and "Other": "Envy builds the wall between Thee and Me thicker and stronger; Sympathy makes it slight and transparent; nay, it sometimes pulls down the wall altogether; and the distinction between Self and not-self vanishes" (7). Throughout the narrative, Masechaba registers her sense of etiquette and humanness by casting in her lot with the patients and the dying while rebuking colleagues of hers who, unbelievably, rides roughshod over their patients. The wall between her and the sick grows thinner by virtue of sympathetic imagination.

Page | 2065 
show how little desirable the desired object was; hence we are now deluded by hope, now by what was hoped for. If it has given, it did so in order to take. The enchantment of distance shows us paradises that vanish like optical illusions, when we have allowed ourselves to be fooled by them. Accordingly happiness always lies in the future, or else in the past, and the present may be compared to a small dark cloud driven by the wind over a sunny plain; in front of and behind the cloud everything is bright, only it itself casts a shadow. (573)

Here, the philosopher is insistent upon disappointment as going with the territory of existence. Chaba is of the kind that seeks her happiness in the others' happiness (Bentham 11). Her abhorrence of senseless human suffering is embedded in a moral compass that foregrounds the sanctity of human life. Indeed, a single death is one too many for her, and, unsurprisingly, she fights with every fiber of her being to preclude patients (no matter how hopeless may be) from being untimely discharged and allowed to die at home. She goes the extra mile to salve her conscience:

Tomorrow I'm going to wake up early and get to the hospital in time. I'm going to be in the lab first thing in the morning and make sure I have all the patients' results before the ward round. I'm going to check their temperatures myself if the nursing sisters haven't done them yet. I'm going to stop others discharging them before they're well enough to go home. I'm going to ask them how they feel, instead of making it up. (45)

3 In his remarkable book Entre-nous: Thinking-of-theOther, twentieth-century French philosopher Emmanuel Levinas, analyzing the phenomenon of "suffering", posits that "The interhuman, properly speaking, lies in a nonindifference of one to another, in a responsibility of one for another..." (100). To put it differently, "Self" and "Other" are bound in a relationship of help and sympathy. The significance of human life forfends insensitivity to your neighbour's woes. What he terms "'the vision' of the Face" refers to "the taking upon oneself of the fate of the other". The "Face" in Levinas' philosophy somewhat takes pride of place as it points to that person through whom the "I" seeks to display proof of the depth of his humanity. Alterity, says Levinas, does not boil down to "a simple exchange of courtesies that has become established as an impersonal commerce' of customs" but is located "in the recourse that people have to one another for help" (101). Cultivation of love and justice should take precedence over hate the ultimate corollary of which is that it breeds suffering. The Latvia-born French thinker regards the notion of suffering absurd. He writes: "the very phenomenon of suffering in its uselessness is in, principle, the pain of the other" (98). Thus the construction of the "Self" is unfailingly interwoven with www.ijels.com
Under-resourced and under-staffed hospitals that culminates in a high incidence of patient deaths; destitution; grisly outbursts of xenophobic sentiments; racial tensions; (corrective) rape: all this pricks her conscience unremittingly, and, lo and behold, underpins her unflagging mettle to push back on man-made woes. A deep sense of despair overwhelms her as she beats her chest about her inability to make a difference:

I don't know who I am anymore. I don't know what defines me. I feel like a failure. I'm not a saint, I'm not like Mother Teresa, Florence Nightingale, Albertina Sisulu. I'm not like those people. I don't know how to be like them. I don't know how to wake up every day and have patients cough MDR-TB into my face, and not mind. I mind. I want to be some kind of hero, but I don't have it in me. (56-57)

The people mentioned in the foregoing were success stories when it came to came to caring for the needy and championing human rights. Thus by developing a sense of identification with them, Masechaba strikes a blow for "otherness", thereby acting upon principles that cut across racial and ethnic boundaries. Regrettably, she has her work cut out living out her humanist principles. She lives in a world where hate of any hue makes people tick. Nothing daunted, she puts up a stiff compassionate pushback against those hell-bent on tearing apart humanity. Actually, she views human relationships from an inter-human perspective $^{3}$. The dysphoric pervasive malaise in Period Pain captures, metaphorically speaking, the blatantly gross

what he calls the "for-the-other", i.e., "the most profound adventure of subjectivity, its ultimate intimacy" (99). The "I" has a redemptive ethical responsibility for the "you" that, from a metaphysical perspective, bars him from justifying or gloating over the other's suffering. On no account must the pain of the other be justified, or else it would be the source of all immorality. Harking back to Period Pain, throughout the narrative, the lead character's conduct strives flat out to act on her ethical responsibility for the other, thereby spurning unconscionable discourses whose end game is the negation of the humanity of the other with oftentimes unintended consequences. As it turns out, Chaba of the kind that foregrounds with the utmost force the primacy of human life. One life lost (wantonly) is one too many for her. Her inability to save the patients from the pervasive devastation wrought the medical staff's dereliction of duty pricks her conscience every step of the way. Witness her regrets over Mrs Mazibuko's fate: “It was my job to protect her from him, from all of them, all those vultures, third year students with their logbooks desperate for signatures, signatures at any cost... But I didn't save her. Instead I aided and abetted, facilitated, won her over - and then handed her over. And now she's dead" (32). Chaba's

Page | 2066 
failure of post-1994 South Africa to deliver the goods. Expectations were indeed high amongst the oppressed of yesteryear that the demise of decades of racial injustice would herald an era of plenty in South Africa. The feeling of anticlimax over the new dispensation tinged with anger finds an obnoxious outlet in the rejection of those folks from elsewhere in Africa who migrated to South in search of a better life. As Tshitreke puts it:

In the post-apartheid epoch, while people's expectations have been heightened, a realization that delivery is not immediate has meant that discontent and indignation are at their peak. People are more conscious of their deprivation than ever before. ... South Africa's political transition to democracy has exposed the unequal distribution of resources and wealth in the country. This is the ideal situation for a phenomenon like xenophobia to take root and flourish. (Qtd. in Matsinhe 52)

If anything, the ill embodied by xenophobia feeds on crass destitution. Against a background of poverty compounded the paucity of job opportunities, disgruntled nationals are liable to develop anger that can easily spill over into xenophobic outburst. This starkly shines through Period Pain where black African migrants, not least those from Zimbabwe, are at the receiving end of a raw deal from South

solicitous consideration to the needy means that she, from a Levinasian standpoint, lives for the "absolute weak". Actually, Levinas contends: "The relation to the Face is both the relation to the absolute weak-to what is absolutely bare and destitute, the relation with bareness and consequently with what is alone and can undergo the supreme isolation called death" (104).Chaba is a woman of conscious whose rejection intolerance of any hue feeds into her moral compass.

4 The term "makwerekwere" is a derogatory moniker describing South Africa-based African migrants. Its derogatoriness lies its positioning Africans from elsewhere in the continent as a bunch of 'invaders', disappointingly conspicuous by the gross intelligibility of their language. In an amazingly stunning research paper, entitled, "Africa's Fear of Itself: the ideology of Makwerekwere in South Africa", David Mario Matsinhe is at pains to delve into the root causes of the scourge of xenophobia in post-racial South Africa through the perspectives of the late German Sociologist Norbert Elias. After a rapid review of the literature pertaining to xenophobia in South Arica, Matsinhe picks holes in each of the scholarly articles that he went through before coming to his own theory. Out of intellectual honesty he admits that "there are grains of truth in these explanations", he, nonetheless, avers that "they only scratch the surface of the problem" (298). Matsinhe, speaking through the perspectives of Elias, contends that any analysis of "antagonistic relations between groups that resemble www.ijels.com
African nationals. The animus against those derogatorily nicknamed "Makwerekwere"4, is somewhat inscribed in post-apartheid South African social fabric. As she seeks to drive a wedge between her daughter and her friend Nyasha, Chaba's mother resorts to a poisonous narrative that frames black foreigners as a bunch of "aliens" intent upon destroying their host country: "These kwerekwere, Masechaba, they'll use their black magic to steal your intelligence, your whole future. Everything you've worked so hard for will be gone, and you'll be left with the nothing they arrived in this country with" (38). Xenophobic slur is blind to competency. The foreigner is viewed through the lens of a selfish person with an eye on the chance, regardless of his or her potential utility to the host country. Despite being a competent physician and bringing to the party her expertise, Nyasha struggles to fit in. She is a "surgeon extraordinaire". Granted. But she is slow in moving up the career ladder owing to her foreignness: "...it was well known in the hospital that if it wasn't for her foreign nationality, she would already be a consultant obstetriciangynaecologist" (39). Chaba's submission that she "feel [s] bad about how our country treats them" (41) speaks to an insightful understanding of nationalism anchored in tolerance and hospitality towards foreigners of any extraction. Matlwa's character appeals to her fellow countrymen to come to their senses in view of their past: "We should know better, what with apartheid and all" (41).

each other" cannot yield academic positivity unless it takes account of the "socio-emotional dynamics of the groups in question" (298). According to Matsinhe, Norbert Elias spots a "crucial feature" that hallmarks relations of "this type", to wit the physical traits on the basis of which the established differentiates themselves from the outsiders, with the former casting themselves in good lights while viewing the latter though negative lens. Thus Elias, says "Almost everywhere members of established groups and, even more, those of groups aspiring to form the establishment, take pride in being cleaner, literally and figuratively, than the outsider groups" (Qtd. in Matsinhe 293). The negative perception of the outsiders, in Matsinhe's estimation, creates in the fullness of time a sense inferiority in the weaker groups "wherein members of the former measure their personal and self-worth according to the social standards of the latter" (293. In the post-1994 South African subconscious, the "makwerekwere" is a kind of wet blanket at whose door the ills plaguing the New South Africa are laid: "In South African imagination, the word 'foreigner' is an emotionally charged signifier for African foreign national or makwerekwere, whereby African bodies become literal texts on which some of the most graphic and scrutable (sic) messages of aversion are written" (302-3). The asymmetrical nature that characterizes colonizer/colonized relations replicates itself in democraticera South Africa, with local South Africans viewing their fellow Africans as 'outsiders'.

Page | 2067 
Due to their long history of subjection to oppression, black South Africans ought to develop empathic feelings towards their fellow Africans. The horrors of the past are still lingeringly painful to be repeated against other categories of people in any shape for form. But Matlwa teaches us that in a land beset by crass poverty, nationalism ${ }^{5}$ can easily be drawn upon as a vector of xenophobic sentiment the hallmark of which is a sickening inability to ride above culture differences. Actually, what marks off xenophobia as "New" racism from "Old" racism is its rejection of the "Other" on the basis of ethnic background. Balibar contends that:

\begin{abstract}
Ideologically, current racism ... fits into a framework of 'racism without races' which is already widely developed in other countries, particularly the Anglo-Saxon ones. It is a racism whose dominant theme is not biological heredity but the insurmountability of cultural differences, a racism, which, at first sight, does not postulate the superiority of certain groups or peoples in relation to others but 'only' the harmfulness of abolishing frontiers, the incompatibility of lifestyles and traditions. (21)
\end{abstract}

"New" racism inscribes itself in a form of praxis that registers a blank refusal of the abolition of cultural and

\footnotetext{
5 The word "nationalism" has generated a huge scholarly literature and, accordingly, contentions debates due to its intricacy. In his seminal 1995 book, Banal Nationalism, Michael Billig flags up the difficult of precisely defining nationalism. Describing "nationalism", Billig posits that it is "broadened as a concept to cover the ways that established nation-states are routinely reproduced" (16). As regards, Ernest Gellner, "nationalism is primarily a political principle, which holds that the political and the national unit should be congruent" (4). In the same breath, he speaks of nationalist sentiment as being "the feeling of anger aroused by the violation of the principle, or the feeling of satisfaction aroused by its fulfilment" (1). The nationalist principle, in Gellner's books, can be dented in no end of ways. But there one key violation of the nationalist principle cannot leave those ruled cold: "... if the rulers of the political unit belongs to a nation other than that of the majority of the ruled, this, for nationalists, constitutes a quite outstandingly intolerable breach of political propriety" (1). Billig foregrounds the significance of history of nationalism to a people's consciousness about nationhood and its psychology of national attachments (16). Put it differently, it is history that spawns "beliefs about nationhood, and about the naturalness of belonging to a nation" (16) It is noteworthy that Billig goes out of his way to burn some many a sociologist and social psychologist for their tunnel vision understanding of nationalism which accounts for their projection of "nationalism onto others"
}

ethnic frontiers. The "stranger" is looked on as an individual driven by a desire to upend the cocoon of ethnic harmony in the host society, and, consequently, made to feel alien. In Period Pain, the exclusion of foreigners plays out in the most inhuman of ways. Nationals grudge black migrants their access to scarce resources, going as far to condescend to them. Chaba angrily bemoans the ill-treatment of black foreigners at the hands hospital staffers:

I hate the Obstetrics and Gynaecology staff. I hate the environment, I hate the smells. The nursing sisters there are mean and cruel, especially to the foreign patients. They call them dirt. They shout at them for coming in the middle of the night without antenatal books. They ask them why they fill up our wards. ... They scrunch their noses when they examine them. They laugh at their names in Sesotho, isiXhosa, isiZulu, even thou they know they can't understand. (48)

Deserving elaboration is a function of language as a decidedly effective tool in the service of exclusionary practices. The sustainability of any ideology rests with the resort to discourse. It is through the medium of language that acts of human conduct acquire meaning: "The word accompanies and comments on each and every ideological act. The processes of understanding any ideological

and naturalization 'of 'our' nationalism out of existence"(16). The main weakness of such theories lies in the fact that they ignore what is called "banal nationalism" (16). If anything, Billig contrasts what he calls "banal nationalism" with "the overt, articulated and often fiercely expressed nationalism of those who battle to form a nation" (16). Day in and out, in established nations, events occur that recall the achievement of nationhood: "national identity ... is remembered because it is embedded in routines of life, which constantly remind, or 'flag' nationhood" (38). What Anderson calls "reminders" or "flaggings" are so commonplace that they are taken for granted. The raising of a flag, for instance, has lost its novelty in established nations. The remembering episodes that are enacted every day to honour nationhood is a remembering of sorts. Billig, to illustrate his point, takes the national flag as an example: "The national flag, hanging outside a public building or decorating a filling-station forecourt, illustrates this forgotten reminding. Thousands upon thousands of such flags each day hang limply in public places. These reminders of nationhood hardly register in the flow of daily attention, as citizens rush past on their daily business" (38). Key to Billig's premise in Banal Nationalism is his counter to social scientists who develop a develop a tendency to confine nationalism to particular social movements rather than to nation-states. 
phenomenon at all (be it a picture, a piece of music, a ritual, or an act of human conduct) cannot be operated without the participation of inner speech" (Viloshinov 42). The cruelty of xenophobic violence is commensurate with the hate that betrays itself in it. The "stranger" is the butt of hate due to the threat that he or she supposedly poses. Migrants are indeed scapegoated. They go through the gauntlet of a killing spree because of a fear that they are thought to epitomize. That is, locals who already live in reduced circumstances - what with economic deprivation- fear being corned into even more destitution by foreign African nationals who fight with them over meager resources. The human toll exacted by a party of 20 South Africans "set [ting] a street of shops in Sechaba township alight" (73) is downright blood-curdling:

Throughout the day the TV has been ablaze with burning shacks, burning shops and burnt people. The streets are crawling with bloodthirsty men calling for foreigners to leave the country. ... They showed images of a naked man being dragged by a mob of boys, blood gushing from his head, and then an image of a group of policemen pouring water over the body of an elderly woman. Hammers, axes, knives, bottles, sticks, rocks, men, women, children, animals everywhere. (75)

As it turns out, the wave of "New Racism" violence against South Africa-based migrants from other African countries belie the sanctimoniousness of the Rainbow Nation. Chaba's bitterness about the inhumanity gripping her compatriots is writ large as she scratches her head endeavouring to fathom out the rationale behind the horrendous fate meted out on African migrants in South Africa: "I tell her [my mother] how appalling it is that we've become the very thing we fought so long and so hard to destroy" (49). South Africans should better than to take it out on Africans from elsewhere. They know what it means to experience injustice. From a moral perspective, Masechaba's mum is not, sad to say, cast in the same mould as her: "She [Ma] insists that foreigners are crafty, and that Nyasha is only being my friend to steal all my knowledge and overtake me. This is what foreigners like to do, she says. They come to our country to take from us all the things we fought for" (52). Chaba's mother's animus against Africa migrants is profoundly embedded in her psyche, so that she can't brook her daughter's friendship with a Zimbabwean. A touch of irrationality shows in her deep-rooted rejection of Nyasha. Chaba complains that: "When I go home on weekends she makes me take off my clothes at the door; she doesn't want me coming into the house with Nyasha's charms and black magic" (52). The mother unavailingly bends over backwards to teach her daughter to hate white people and foreigners alike but to no avail (52).

South Africans' xenophobic bend against black migrants betoken a warped view of nationalism based on ethnicity. Ethnicity-spiked nationalism is one that conceives of nations as "defined by a shared heritage, which usually includes a common language, a common faith and a common ethnic ancestry" (Qtd. in Akpeninor (370). Ethnonationalists view "nations" as revolving around ethnic origins. There is more to the meaning of "nations" than sheer ethnic genealogy. In point of fact, ethno-nationalism fosters exclusion as against inclusion. Political philosopher Michael Neocosmos argues that xenophobia is tantamount to citizenship denial:

Exclusion from community means exclusion from citizenship, its rights and duties, as it is the latter which defines community membership of the nation in particular. Xenophobia is thus intimately connected to citizenship, to the fact of belonging or not belonging to a community, often but not exclusively to a nation. ... Xenophobia is about the denial of social rights entitlements to strangers (village, ethnic group as well as nation) not just to foreigners as conceived by the law. (14)

Harking back to the politics of xenophobia in Period Pain, locals picture themselves the migrant as a "non-citizen". The awful plight of African foreign nationals in South Africa is all the more unwarrantable since, back to the days of apartheid, African nations fought tooth and nail to get their fellow black South Africans off the hook of harrowing racial oppression. Kopano Matlwa's point, it bears stressing, is to urge South Africans to bite the bullet and accept black migration as payback for the invaluable contribution of African countries to the lofty struggle against institutionalized racism. Solomon and Kosaka write appositely that South African xenophobia defies logic:

Such xenophobia is particularly problematic because of the historical universality of the struggle and the unprecedented international, but mostly African, support it received in the 1980s. It is somewhat ironic that the Africans that currently face such exclusionary rhetoric hail from the same nations that harboured and nurtured the liberation struggles by proving sanctuary, education and sustenance to the fleeing comrades and cadres of the AND who are today's gatekeepers. Opposition to the apartheid state served to unite, irrespective of nationality, and the identities thus constructed took on a PanAfrican context. (8) 
Here, the ingratitude of black South Africans vis-à-vis their fellow Africans is emphatically brought to light. Key to teasing out black South Africans hostility against black foreign nationals is its dissection through postcolonial lens. Michael Neocosmos posits, actually, that an understanding of "political identities and by extension xenophobia" necessities going beyond "an analysis of the political economy of migrant labour" and making sense of "this migrant labour from a perspective which emphasizes politics, particularly citizenship" (25). According to Neocosmos, the post-1994 xenophobic discourse was shaped around the labelling of migrant labour "a bad thing" and, as a consequence, must not be "allowed to persist in the 'new' South Africa as it was contaminated by apartheid. The corollary of this move was the replacement of foreign labour by South African labour and the replacement of migrant labour by urbanized labour" (78). Also, the "discourse" of exceptionalism, in Neocosmos's estimation, factors into the rejection of black foreigners in South Africa:

This discourse is not simply founded on the belief that South Africa is an exception in Africa because of its industrial development, but includes a tendency to see the rest of the continent as rural, backward, immersed in poverty and politically unstable and corrupt. From this notion follows the conception of Africans as wanting to acquire the benefits of our democracy, economy and so on. (78-9)

Interestingly, there is a historical edge to the grisly displays of intolerance and xenophobic attitudes against blacks from other African countries. Amongst the theories being put forward to get to the bottom of post-apartheid xenophobia features the contention that it is a left-over from apartheid. Xenophobia and stigmatization of immigrants from mostly Asia and neighbouring countries was a phenomenon under British colonial rule and apartheid. Thus the targeting of black migrants by South African blacks is history-informed. Magidishima et al. argue that:

Based on apartheid's legacy relating to the stigmatization of migrants, which manifested in the pass system, post-apartheid South Africa has not escaped the grip of this 'othering' of migrants. This is why South African citizens, who for example migrate from one province to another, are 'othered'. This seems to conform to the apartheid's state logic of confining people according to race, place and space. Those who violated the confinement were not only victimized, but also arrested and in some

${ }^{6}$ See my people entitled “André Brink's Sense of Anticlimax over the New Dispensation in Modern-Day www.ijels.com cases, violently dealt with, and reminded that they were not of 'white' South Africa. (106)

Indeed, the weight of history hangs heavily on democraticera South Africa. Decades of domination have had lingering effects on every aspect of life in the Rainbow Nation. The seemingly intractable culture of violence that has eaten so deeply into South African social fabric doubtless stretch its roots to the oppressively weighty yoke of subjugation under which South African black population had lived from the moment of colonization to the end of apartheid. Frantz Fanon's submission that "Not with impunity does one undergo domination" (41) buttresses our point that the black South African is still psychologically kind of linked to his white compatriot, be it of the past or the present. In Period Pain, Chaba slams the lingering fallout from history as she tries to make sense of the dead hand of violence and hatred (mostly for foreigners from elsewhere in the continent) in her country. She acknowledges being ashamed. In the same breath, she, nonetheless, points out that her fellow black South Africans are not the villain of the piece: "It's the white people's fault, Lord. Everything is. They taught us to hate ourselves. They made us like this. We weren't like this before they came. This is not the way we would have been if they hadn't come and messed everything up for everyone" (74). This mindset feeds into Blacks' perception of white people in the new dispensation in South Africa. The chickens are coming home to roost for many a white South African ${ }^{6}$; the racial shoe is somewhat on the other foot. There is a nefarious trend amongst the downtrodden of yesteryear towards putting post-apartheid travails at the door of South Africans of white extraction. This fuels the undercurrents of revenge noticeable in the way white South Africans are treated by their black countrymen. No stratum of social life seems immune to this groundswell of revenge. In post-1994 South Africa, white people are no stranger to housebreak-ins, rape, murder. The agonizingly harrowing backstory to the hospital admission of a white lady is a bleak reminder of a country that has difficulty in drawing a line under its past:

On call, last night, the paramedics brought in
this white lady at about 1: 30 am at home with
her boyfriend when four men broke into their flat,
raped her, shot her in the head and ransacked her
house. ... On my way to the blood bank I heard
one of the paramedics telling a nursing sister that
the police had found blood splattered across her
living room walls and her boyfriend had died at
the scene, but she hadn't been told yet. (43)

South Africa." In Research Journal of English Language and Literature, Vol.5, Issue 4, 2017 (Oct.Dec)

Page | 2070 
Arguably, racial tensions still plague the Rainbow Nation twenty-five years after the demise of apartheid. The psychological and physical scars in the backwash of decades of race-based oppression disfigure, as it were, the face of the new South Africa. A black perspective of the racial dynamics in modern-day South Africa locates "whiteness" within a disdain-spiked praxis geared to mediating the destruction of the black man. That's why Nyasha regards any forbearance towards white people as self-loathing. In a long tirade, she is at pains to lay out the rationale behind the ill-informed call to allow white doctors and nurses into post-liberation South African hospitals:

We know we hate ourselves as black people. That we know. But now we are exposing ourselves to white people, too. Now we're exposing this dark strain of self-hatred on our race. We are giving them evidence that we are indeed a foolish, selfloathing people. A thing to be pitied. ... These girls have only been working a few months and already they're enriching the industries that strive to oppress us instead of building our communities...We need to stop bending over backwards, breaking our backs to make them feel comfortable, welcome, safe. Put a white man in charge and he'll only serve his interests. (50-1)

Resentment over the horrors wrought by the colonial enterprise will sear forever the postcolonial subject. But it bears stressing that a continual mourning over that gruesome chapter in the history of humanity may irretrievably blight any agency aimed at fostering racial harmony. This is Kopano Matlwa's stance. Speaking through her lead character, Masechaba, she exhorts Africans to try and come to terms with the human toll of the past and look ahead although they have every reason in the world to feel hard done by. In reply to Nyasha's tirade, Chaba says:

She hates white people and blames them for everything. Maybe she's right, maybe they are to blame. But it is what it is. What's happened has happened. We can't go back, and we certainly can't change who we are to try to avenge the past. She says we black South Africans are too accommodating, too soft. 'Weak' and 'pathetic' are the words she uses to describe us. (51)

,Chaba is conscious that the advent of a multiracial and multiethnic harmony in the South African context can only be enacted successfully through drawing a line under the past, gruesome though it was. Nineteenth-century German sophisticated philosopher Friedrich Nietzsche posits that too much historical sense has the potential for harming the living being. He urges that man sort of take a leaf out of the www.ijels.com animal's book. That is, he emphasizes forgetting as a gateway to happiness. He writes in Untimely Meditations that,

it is possible to live almost without memory, and to live happily forever, as the animal demonstrates, but it is altogether impossible to live at all without forgetting. Or, to express my theme even more simply: there is a degree of sleeplessness, of rumination, of the historical sense, which is harmful and ultimately fatal to the living thing, whether this living thing be a man or a people or a culture. (62)

One cannot live happily while constantly turning the clock back. Masechaba's consciousness about the insignificance of living with the traumatic memory of apartheid justifies her all-out drive to push for forgiveness, and to strike a blow for the triumph of universal values of peace and dignity. Indeed, her crusade has no ethnic or racial colouring. Nicknamed "a kwerekwere lover behind [her] back", Chaba takes a lot of flak from her colleagues for siding with black foreigners from other African countries (79). When "One of the Nigerian doctors was spat on by a patient" on the grounds that "she didn't want to be examined by a cockroach," (79), Chaba felt it as a duty to step up to the plate: "I'm going to draw up a petition. I'll print it and distribute it around the morning departmental meetings" (80). The endgame of this no-nonsense move is framed in these terms: "Then the world will see that this isn't who we are, and that those thugs out there going around killing foreigners don't represent the majority of us. Maybe this petition will bring this madness to an end" (80). Chaba goes down this treacherous road to salve her conscience. The initiative got off to a good start with a glowing newspaper article about Chaba, calling her "a young activist, an inspiration" (81). The positive feedback from the press coupled with a potential radio interview give a welcome fillip to her endeavour; so, to press her advantage, she mulls over the idea of "organizing an anti-xenophobia march in the community" (81). Despite exhortations from several quarters to back off "this petition nonsense" (as it ruffles many feathers in her community and even beyond), Chaba is having none of it. Eventually, she get hers fingers burnt very badly over her project: she is gang-raped. The rape is meant as a corrective action for Chaba being a quisling to her the community:

They said I was a disappointment that instead of helping my own people, I was running around with kwere-kweres, the very kwere-kweres [Italicized in the novel; so, it is I who underline] that were ruining our country, stealing our jobs, using up grants. ... Spoilt, foolish, children like me needed to be taught a lesson, so others would 
see that the community didn't hesitate to discipline traitors. That said I was lucky they didn't necklace me, like they did to the likes of me during apartheid. (113)

What Chaba was subjected to is "corrective" rape. There is a dividing line (thin though it may be) between simple rape and "curative" rape. This kind of rape has an ideological underpinning, namely that it aims to putting the victim back on the straight and narrow. Perpetrators of "curative rape" target those women they regard as being on the wrong side of gender or heteronormative values (Morffett 132). Thus, they pass themselves off, so to speak, as guardians of a social order anchored in a patriarchal system which is put in jeopardy by a crop of women who are a law unto themselves. The latter, in the mental universe of rape perpetrators, deserve correcting as they pose a serious threat to society. In her substantiation of "corrective rape", for instance, Dr Phakama underscores the patriarchal edge to the sexual assault inflicted on Chaba, saying to Chaba that it is "a rape to correct what their society deems abhorrent behaviour. She says in our society many people don't like foreigners, and the men who raped me might have seen my behaviour as threatening societal norms, and felt it their duty to correct me" (120). (The use of the possessive adjective "their" as against "our" is a measure of Dr Phakama's rejection of rapists' hidebound mindset.) One way in which women are more often than not corrected is through bodily violence. A key hallmark of sex-based violence is, in Moffett's books, that it is the lot of women. Consequently, it bolsters up male patriarchal stranglehold: "women are more likely than men to be raped; and women are invariably raped by men. In other words, sexual violence is an instrument of gender domination and is rarely driven by a racial agenda" (134). The lack of racial motivation that characterizes rape stems from the fact that it is "like most crimes intra-communal (that is, it is usually committed by 'insiders', not 'outsiders')" (134). The exaction of sexual violence on women is a measure of their subservient place at the gender pecking order: "Women are sexually assaulted because they are women: not individually or at random, but on the basis of sex, because of their membership in group defined by gender" (MacKinnon 129). The experience of rape (be it corrective or otherwise) packs a punch in terms of psychological cum physical toll. Women who have been subjected to rape develop low self-regard as time wears on, and self-loathing perceptions of themselves. So traumatic is the experience that the victims don't have it in them to put it into words. Masechaba's case is telling:

There is no vocabulary for the pain I feel. How do I construct a sentence that explains that they made me into a shell of myself? . . . How do I explain that what they stole from me is more than just my 'womanhood' or any of that condescending stuff people like to talk about, but a thing that once lost can never be found because it is unnamed? How do I explain that the languages at my disposal can't communicate the turmoil I have inside? That it's more than my dignity they stole, it's more than a violation they subjected me to? That it would have been better to die than to be spooned out left that way. (109)

By virtue of its breaking the subject's psyche, "rape" fits the definition of "trauma" as put forward by Cathy Caruth. In Unclaimed Experiences she defines it as follows: "In its most general definition, trauma describes an overwhelming experience of sudden or catastrophic events in which the response to the event occurs in the often delayed, uncontrolled repetitive appearance of hallucinations and other intrusive phenomena" (11). To be sure, a traumatic encounter like rape might be stinking hard to narrate. The impossibility of enunciating a rape event lies in its quasi 'unspeakability' or, as Caruth suggests, its "incomprehensibility" owing to the fact that it "is experienced too soon, too unexpectedly" (UE, 4). Interestingly, "belatedness", Caruth points out, is what constitutes trauma, for consciousness about rape comes only after it has already occurred. She contends that "the impact of the traumatic event lies precisely in its belatedness, in its refusal to be simply located, in its insistent appearance outside the boundaries of any single place or time" (Trauma: Explorations in Memory, 9). The event bruises the subject's consciousness in so poignant a way that the victim does not feel equal to recounting it. Oftentimes, words, notwithstanding their cathartic value, can turn out be inefficient in articulating a traumatic occurrence. Chaba registers the impossibility of enunciating what befell her: "Dr Phakama wants me to say it. She says it will help. She says by putting it in the past tense I can overcome it. But still when it's your own life and you're living it, there is never so clear a distinction. I'm still being raped even now, even when I'm not" (118). The memory of a traumatic encounter never leaves the survivor. Rather, it keeps on haunting him at every turn. This belated pattern of flashbacks defines trauma and, significantly, compounds the mediation of a full-blown closure. Hence Caruth's submission that "To be traumatized is precisely to be possessed by an image or event" (TEM, 4-5). For all the difficulty of tapping into the tool of language to "narrativize" an event that leads to wounded mind, Caruth foregrounds the Other as being crucial to, if not eliminating altogether traumatic angst, or at least, mitigating it. She writes that "the history of trauma, in its inherent belatedness, can only take place through the listening of 
another" (TEM, 11). Masechaba may have no genuine shoulder to cry on but the pregnancy she conceived from the rape turned out to be a blessing in guise. Upon learning about her conception, she acknowledges wanting to pass on. Nevertheless, she stopped short of having an abortion, electing to carry the baby to full term: "it was her [the baby] life that forced me to live" (150). If anything, the name of the baby says a mouthful: "I named her Mpho because that is what is, because it's not her fault, because she doesn't deserve to have this stain on her future, because I refuse to allow anyone to tell her. She's my Mpho, my gift" (151). Chaba's sanguine reading of her life travails can be read as an appeal to never despair in life. Misfortunes go with the territory of existence; they are sent to try us. When one has experienced a traumatic encounter, the bottom is to be able to pick oneself up from the floor, and turn one's trauma into a spur for meaningful agency.

In the final analysis, suffice it to say that Period Pain is a novel of its time. Set in post-apartheid South Africa with all the social ills plaguing it, the novel arguably serves as a metaphor for the Rainbow Nation. Kopano Matlwa's daunting move to broach themes (that some of her colleagues might consider dangerous ground due to their sensitivity) bespeaks the worldview of a young writer steeped in the consciousness of her time. One of the most important takeaways from the agency and portrayal of her lead character betokens cultivation of love and tolerance as well as forgiveness as a surefire way to rise above hatred of any hue. By submitting that "there is goodness in all us," despite the threat posed to Humanity by bigotry and racism, Masechaba appeals to everyone's better self to mediate a world free from the demons of evil. Her praxis rules out a constant digging up of old memories in that it, from a postcolonial vantage point, has the potential for seriously crippling efforts towards multicultural harmony, especially in a country coming out of decades of racial oppression.

\section{WORKS CITED PAGE}

[1] Akpeninor, James Ohwofasa. Merger Politics of Nigeria and Surge of Sectarian Violence. Bloomington: Authorhouse, 2013.

[2] Allen, John. Rabble-Rouser for Peace: The Authorized Biography of Desmond Tutu. New York: Free Press, 2006.

[3] Basdeo, Vinesh. "Policing Sexual Violence in South Africa: Problems and Challenges" in International Journal of Criminal Justice Sciences (Official Journal of the South Asian Society), Vol. 13 (1), pp. 112-121.

[4] Bentham, Jeremy. Deontology or The Science of Morality: In Which the Harmony and Co-Incidence of Duty and SelfInterest, Virtue and Felicity, Prudence and Benevolence, Are Explained and Exemplified. Arranged and edited by John Bowring. Vol. 1. London: Longman, 1834.

[5] Billig, Michael. Banal Nationalism. London: SAGE Publications, 1995.
[6] Caruth, Cathy. Trauma: Explorations in Memory. Baltimore and London: The John Hopkins University Press, 1995.

[7] Unclaimed Experience: Trauma, Narrative and History. Baltimore and London: The John Hopkins University Press, 1996.

[8] Diaz, Karen R \& Nancy O'Hanlon. Issue Web: A Guide and Sourcebook for Researching Controversial Issues on the Web. Westport, Connecticut: Libraries Unlimited, 2004.

[9] Dickson, Del. The People's Government: An Introduction to Democracy. Cambridge, UK: Cambridge University Press, 2014.

[10] Gellner, Ernest. Nations and Nationalism [1983]. Oxford, UK: Blackwell, 1993.

[11] Habib, Adam. "South Africa-The Rainbow Nation and Prospects for Consolidating Democracy" in African Journal of Political Science / Revue Africaine de Science Politique, Vol.2, No. 2 (December 1997), pp.15-37.

[12] Harris, Browyn. "Xenophobia: a new pathology for a new South Africa" in Hook, D \& G. Eagle (eds.) Psychopathology and Prejudice. Cape Town: University of Cape Town Press, 2002.

[13] Howarth, Jean \& Mike Walton. Moments of Reflection. Heinemann Education Publishers Ltd. Oxford, UK, 1995.

[14] Levinas, Emmanuel. Entre-nous: Thinking of the Other [1991]. Translated from the French by Michael B Smith and Barbara Harshav. New York: Columbia University Press, 1998.

[15] MacKinnon, Catharine A. Women's Lives-Men's Laws. Cambridge, Massachussetts: The Belknap Press of Havard University Press, 2005.

[16] Matlwa, Kopano. Period Pain. Aukland Park: South Africa, 2016.

[17] Magidimisha, Hangwelani Hope et. Al. Crisis, Identity and Migration in Post-Colonial Southern Africa. Gewerbestrass, Switzerland: Springer Publishing AG, 2018.

[18] Marshall, Robert C. [ed.] Cooperation in Economy and Society. Lanham, Maryland: AltaMira Press, 2010.

[19] Mason, Gail et al. Policing Hate Crime: Understanding Communities and Prejudice. London and New York: Taylor and Francis Group, 2017.

[20] Matsinhe, David M. Apartheid Vertigo: The Rise in Discrimination against Africans in South Africa. Lon and New York, Taylor and Francis Group, 2011.

[21] — "Africa's Fear of itself: The Ideology of Makwekwere in South Africa," in Third World Quaterly, Vol. 32, No. 2, 2011, pp. 295-313.

[22] Moffett, Helen. "These Women, They Force Us To Rape Them: Rape as Narrative of Social Control in Post-Apartheid South Africa" in Journal of Southern African Studies, Volume 32, Number 1, March 2006.

[23] Nel, J. A., \& M. Judge. Exploring Homophobic Victimization in Guateng, South Africa: Issues, impacts and responses" in Acta Criminilogica 21 (3), pp. 19-36.

[24] Naidoo, Kamban. "The Origins of Hate Crime Laws" in Fundamina (Pretoria), vol.22, n. 1, 2016, pp.53-66.

[25] Neocosmos, Michael. From Foreign Natives to 'Native Foreigners': Explaining Xenophobia in Post-Apartheid South Africa: Citizenship and Nationalism, Identity and 
Politics. Dakar, Senegal: CODESTRIA (Council for the Development of Social Science Research in Africa), 2010.

[26] Nietzsche, Friedrich. Untimely Meditations. Ed. Daniel Breazeale. Trans. R. J. Hollingdale. Cambridge, UK: Cambridge University Press, 1997 [First English edition].

[27] Nyamnjoh, F.B. Insiders and Outsiders: Citizenship and Xenophobia in South Africa in Contemporary Southern Africa. London: London Zed Books Ltd., 2006.

[28] Ross, Jeffrey Ian. (ed.) Encyclopedia of Street Crime in America. Forward by Francis T. Cullen. Los Angeles: SAGE Publications, Inc., 2013.

[29] Schopenhauer, Arthur. On Human Nature (Essays Partly Posthumous) in Ethics and Politics. [1897] Selected and translated by Thomas Bailey Saunders. London: Sonnenchhein \& CO., 1902.

[30] Solomo, Hussein, Hitomi Kosaka. 'Xenophobia in South Africa: Reflections, Narratives and Recommendations' in Southern African Peace and Security Studies, Volume 2, Number 2, (21 June 2019).

[31] Soyinka, Wole. "Views from a palette of the cultural rainbow" in The Meaning of Mandela: A Literary and Intellectual Celebration. [ed. Xolela Mangcu] Foreword by Archbishop Desmond Tutu. Cape Town: HSRC Press, 2006.

[32] Vilošinov, V. N. Marxism and the philosophy of language [1929]. Trans. Ladislav Matejka and I. R. Titunik. Cambridge, Massachussetts: Havard University Press, 1986. 